\title{
左心房機能の超音波評価
}

\author{
石井 徹子 \\ 東京女子医科大学病院心臓病センター循環器小览科
}

\section{Echocardiographic Evaluation of Left Atrial Function}

Tetsuko Ishii

Department of Pediatric Cardiology, Tokyo Women's Medical University, Tokyo, Japan

\section{左房機能評価の意義}

左房機能を評価することにより心機能をより詳細に把握することが可能となる. 例えば, 左室拡張能の評価は一 般的に僧帽弁口血流のドプラ波形を分析する方法が広く知られていて, 拡張能低下の所見としてまず $\mathrm{E}$ 波が減高し $\mathrm{A}$ 波が増高する.これは左室弛緩障害に対し, 左房の能動的左房駆出量の増大により代償している状態である. しか し, さらに左室拡張障害が悪化した状態で認められる流入ドプラ波形の偽正常化, つまり $\mathrm{E}$ 波の増高と A 波の減高 は左房収縮の低下, すなわち左房よる代償機構の破綻であり, そしてそれに引き続く左房圧の上昇と左室拡張末期 圧の上昇であることがわかる，以上のように僧帽弁口流入波形の変化は，単に拡張能の変化をみているのではなく， 左房機能にも依存している. 左房機能を知ることで心不全がどのように代償され，どのように破綻しているのかを より詳細に評価することが可能になるのである。

左室拡張能低下では, 左室の弛緩障害, 左房代償機構の破綻, 左房圧の上昇, 心房壁の伸展, 左房容積の増大と循 環動態が増悪していく．このような理由から左房容積は僧帽弁口血流のドプラ波形や組織ドプラが急性的な血行動 態を反映するのに対し, 長期にわたる左室流入圧の上昇を反映していると考えられている. 左室拡大が一つの左心 機能の指標であるように, 左房容積は左房機能を示す指標の一つであるが, その中においても長期的な血行動態を 反映すると考えられ，拡張障害にからくるさまざまな心血管イベントのよりよい予測因子になりうるものと考元ら れている1).

このように左房最大容積の血行動態評価における有用性を考えると, 計測值の標準化が困難な小児心臓エコー計 測值において小児における正常值を示した本研究の臨床的意義は大きいものと思われる. また比較として示された 2D での正常值は, その簡便性を考えると日常診療での有用性は高いと考えられ, 今後臨床での有用性を示す研究が 待ち望まれる。

\section{その他の左房機能評価方法}

左房容積以外の左房機能評価方法を記載しておく. 著者が提示した左房容積変化曲線以外には, Strain, Strain rate などは導管機能, 心房収縮機能, リザーバー機能を分けて数值化でき, また左室の挙動に左右されにくい指標として, 有用性が期待される。しかしながら小児領域での報告は少ない.

\section{1. ドプラ波形を用いた方法}

\section{1) Atrial fraction ${ }^{2)}$}

僧帽弁流入ドプラ波形から算出される左房流入血流に扔ける心房収縮よる流入血流の割合, つまり僧帽弁左室 流入ドプラ波形において A 波の流速時間積分 (VTI)の僧帽弁流入ドプラ波形 VTI に対する割合.

2) Atrial ejection force ${ }^{3)}$

ニュートン力学の法則のとおりに, 質量と加速度の積がエネルギーであることから, 心房収縮期のうち加速時 
間 $(\Delta \mathrm{T})$ に心房が生じるエネルギーを, 加速度がほぼ一定と仮定して血液質量 $($ 血液密度 $(1.06) \times 0.5 \times \Delta \mathrm{T} \times \mathrm{A}$ 波 最大流速 $\times$ 僧帽弁口面積 $) \times$ 加速度 $(\mathrm{A}$ 波最大流速 $/ \Delta \mathrm{T})$ 加 $0.5 \times 1.06 \times$ 僧房弁口面積 $\times \mathrm{A}$ 波最大流速 ${ }^{2}$ と算出 される。

\section{3) 肺静脈血流ドプラ波形}

肺静脈ドプラ波形の流速や時間速度信号面積 (velocity-time integral)を用いて, S 波はリザーバー機能, D 波が導 管機能を, 心房収縮に伴う引き达み血流である A 波は心房収縮機能のパラメーターとされているが, いずれも左 房の後負荷である左室拡張末期圧に影響を受ける4-6).

\section{2. 心房容積を用いた方法}

一般的に計測されてきた最大左房容積 (僧帽弁開放直前)に加え，最小左房容積(僧帽弁閉鎖時)や, 左房収縮前容 積(心電図の P 波の始まり)の計測をすることで以下のような左房機能評価が可能となり, 心房のリザーバー機能, 心室拡張早期の心房導管機能, 能動的心房収縮機能の評価が可能となる.

(1) 総左房駆出量 最大左房容積 - 最小左房容積

(2)受動的左房駆出量 最大左房容積 - 左房収縮前容積

(3) 能動的左房駆出量 左房収縮前容積 - 最小左房容積

左房容量の評価には心尖部四腔断面, 二腔断面を用いて, Biplane Area Length 法あるいは Single Plane Area Length 法を用いて左房腔をトレースして計測する.三次元エコー法を用いた計測法は本研究でも述べられているように, MRI との比較研究で最も正確な評価が可能と考えられている77. 加えて本研究で示されているように自動トレース を用いることで心周期に伴う容積変化曲線が得られるため, 従来法よりも容易に各心周期での左房容積が算出され る。しかしながら心拍数の早い小児においては超音波の Frame rate との関係で十分に正確な容積変化曲線を得るこ とは困難であり, 関心領域にしぼった画像の収集など Frame Rate を保つためのデー夕採取を心がけるとともに, 検 查限界をふまえた検査結果の解釈が必要である。

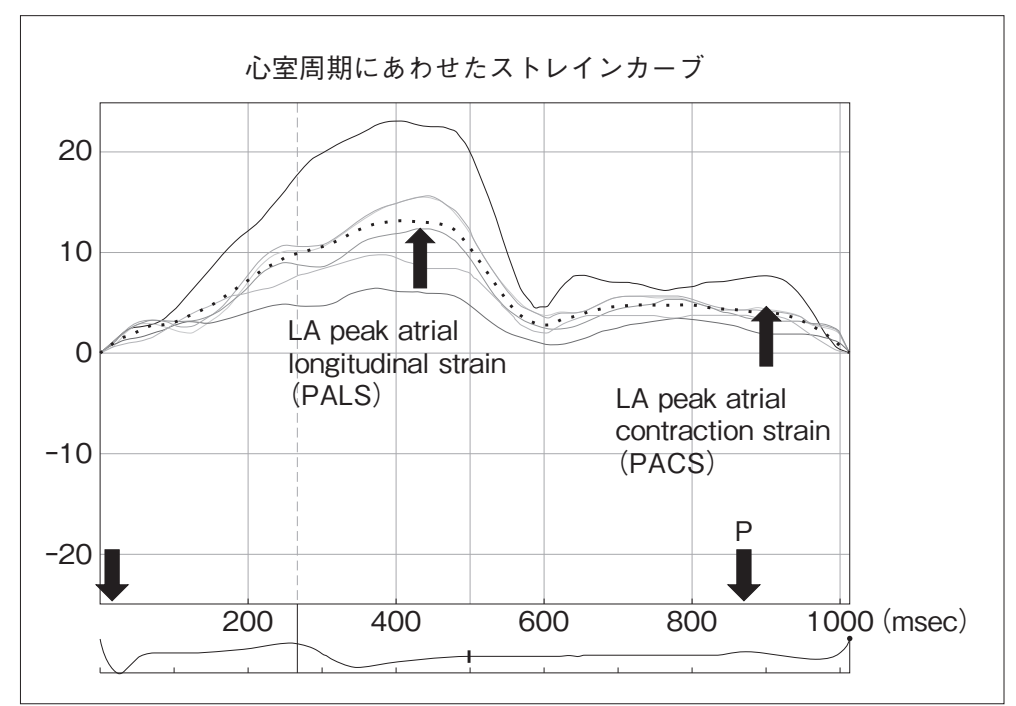

Fig. 1 QRS から始まる心室周期にあわせた左房ストレインカーブの 1 例 実線は 6 分画された左房壁のストレインカーブを, 点線が 6 分画のスト レインの平均である. 
3. その他

組織ドプラ (TDI)や組織トラッキング法を用いた Strain, Strain Rateによる評価方法である. TDI の角度依存性や, 心室に比較し壁が薄く体表面からの距離が遠い左心房におけるトラッキングの精度, Frame rate などの検査上の限界 は従来の心室機能評価と同様である.

心周期のストレインの変化を示したストレインカーブには心周期の始まりを心室つまり QRS にあわせる方法と, 心 房つまり P 波にあわせ解析する方法がある. 図に心室周期にあわせたストレインカーブを示す. QRS のあとの最大ス トレイン (peak atrial longitudinal strain)が reservoir function, 拡張末期のP のあとのストレイン (peak atrial contraction strain)が atrial booster function を, その差が導管機能を表すと考えられている. Strain rate に関しては, 解析に用いる心 周期によらず収縮期 strain rate (SSr) が reservoir function, 拡張早期 strain rate (ESr) が導管機能, 拡張末期 strain rate $(\mathrm{ASr})$ atrial booster function の指標とされている8,9).

\section{【参考文献】}

1) Douglas PS: The left atrium: a biomarker of chronic diastolic dysfunction and cardiovascular disease risk. J Am Coll Cardiol 2003; 42: 1206-1207

2) Manning WJ1, Leeman DE, Gotch PJ, et al: Pulsed Doppler evaluation of atrial mechanical function after electrical cardioversion of atrial fibrillation. J Am Coll Cardiol. 1989; 13: 617-623

3) Manning WJ, Silverman DI, Katz SE, et al: Atrial ejection force: a noninvasive assessment of atrial systolic function. J Am Coll Cardiol $1993 ; 22: 221-225$

4) Castello R, Pearson AC, Lenzen P, Labovitz AJ: Evaluation of pulmonary venous flow by transesophageal echocardiography in subjects with a normal heart: comparison with transthoracic echocardiography. J Am Coll Cardiol 1991; 18: 65-71

5) Chen YT, Kan MN, Lee AY, et al: Pulmonary venous flow: its relationship to left atrial and mitral valve motion. J Am Soc Echocardiogr 1993; 6:387-394

6) Manning WJ, Leeman DE, Gotch PJ, et al: Pulsed Doppler evaluation of atrial mechanical function after electrical cardioversion of atrial fibrillation. J Am Coll Cardiol 1989; 13:617-623

7) T Poutanen, E Jokinen, H Sairanen, et al: Left atrial and left ventricular function in healthy children and young adults assessed by three dimensional echocardiography. Heart $2003 ; 89: 544-549$

8) Sirbu C, Herbots L, D’Hooge J, et al: Feasibility of strain and strain rate imaging for the assessment of regional left atrial deformation: a study in normal subjects. Eur J Echocardiogr 2006; 7: 199e-208

9) Vianna-Pinton R, Moreno CA, Baxter CM, et al: Two-dimensional speckle-tracking echocardiography of the left atrium: feasibility and regional contraction and relaxation differences in normal subjects. J Am Soc Echocardiogr 2009; 22: 299-305 